\title{
Assessment of Managerial Leadership Skills for Effective Sports Administration among Sports Administrators in Bayelsa East Senatorial District, Bayelsa State
}

\author{
Dr. Deemua G.A* \\ Department of Human Kinetics and Health Education, Nigeria
}

*Corresponding Author: Dr. Deemua G.A, Department of Human Kinetics and Health Education, Nigeria

\begin{abstract}
The this study was to examine sport administrators' leaderships traits as indices for effective sports administration among sport clubs in Bayelsa East Senatorial District of Bayelsa State. Three research questions and hypothesis e formulated to the study. Descriptive survey research design was adopted for the study. The population of the study consist 400 sports administrators while 200 of them were used a sample size. A composite sample of the Taro-Yamene formula was used to determine the sample size of the study. A self-structured questionnaire was used by the researcher to gather information for the study. A total of five persons from the department of Human Kinetics and Health Education and Bayelsa State Sports Council were used to validate the questionnaire. The reliability for the instrument used was established using Cronbach's coefficient Alpha method and a reliability coefficient of 0.65 was obtained. Mean and standard deviation were used to answer the research questions while z-test was used to test the hypotheses at 0.05 level of significance. The result showed a significant relationship sports administrators' leadership traits and effective sports administrations. On the basis of the findings, it was recommended that sports administrators should use their managerial skills for improve sports performance among athletes and bridge the medium of communication among the stakeholders of sport should be properly harnessed for effective sports delivery.
\end{abstract}

Key terms: Managerial, Leadership Skills, Sports Administration, Sports Administrators

\section{INTRODUCTION}

Leadership is an important element in directing functions of a group, an organization or management, wherever there is an organized group of people working together towards a common goal, some form of leadership becomes essential. A leader stimulates what is best in a group, unites and provides channels to the unutilized energy and creativity in the group.

Marry Perker Follethas rightly expressed:

"The leader is the person who influences the most, is not he who does great deeds, but he who makes we feel that I can do great deeds".

Leadership is the ability to build up confidence and zeal among people and to create an urge in them to be led (Singh, Gill, Bains\&Brar, 2014). To be a successful leader one must possess foresight, drive, initiative, self-confidence and personal integrity. In the words of the great English Soldier Field Marshal Montgomery, "the capacity and will of an individual rally men and women to a common purpose" is leadership.

In order words, leadership is the act of influencing other people to cooperate towards some common goals which they come to find desirable.

\section{THE CONCEPT OF MANAGERIAL LEADERShIP}

Ibrahim (2016, p. 73) discussed managerial leader as a term that integrates management and leadership into a coherent; the manager-leader dichotomy serves as a way of thinking for managers of sports organization. According to Griffin (1999), leadership is both a process and property, as a process focusing on what leaders actually do, leadership is the use of non-coercive influence to shape the group's or ogranisation goals, motives and behaviours towards achievement of those goals. Mull, Bayless and Jamieson (2005), sees management as influencing operational functions and resources to 
reach a goal and that management is move aware of the human elements, including individual and group feelings, attitudes, sensivity to fairness and operation in the attempt to accomplish something.

Parks and Quarterman (2003), affirmed that managerial leadership is the combination of management and leadership into a coherent integrated concept. Managers are often leaders, not all leaders are necessarily managers. The fact that, a leader influences the behaviours of others, and he/she is being depended upon even if he is not in the management position.

However, management scholars have addressed the practice of management as a process, which implies that managers use a set of ongoing interactive activities such as planning, organizing, directing, controlling and invariably staffing for accomplish goals and objectives of sports organisations (Hersey \& Blanchard, 1988).

\subsection{Managerial Leadership Skills}

The term skill reflects the idea that one's ability to perform managerial tasks is not innate. It can be learned and developed through experience and formal training. Katz, (1974) identified the skills needed by managers of all types of organisations as: conceptual; inter personal (human) and technical. Conceptual skill sees the organization as the whole organization. Interpersonal is the ability to interact with others and coordinate individual and group efforts in achieving an organisation's goal. Technical skill is the specified knowledge, resources used in achieving an organizational goal.

In this regards, Labrich and Labich (1998) identified seven skills of successful managerial leaders in sports organisations that they trust their subordinate; they develop a vision; they keep their cool; they are expert; they invite dissent, they simplify; they encourage risk (p. 75).

For managerial leaders to effectively relate to their subordinates, they should play the role of disseminators. Managers in the role of passing information on others in the organization or work unit. In order to decide to which leadership skill is most appropriate, managers should be able to assess the readiness and willingness and ability of their followers to perform task. Telling and selling are both primarily leader oriented and one-directional communication. Participating and delegating one primary follower-oriented and two directional communication (Hersey, Blanchard \& Johnson, 2001).

\subsection{Communication in Sports}

Generally put, communication involves people interacting with one another to convey information. The most obvious form of communication is linguistic (expressing oneself verbally or in writing), but body language, behavioural mannerism and many other inter personal signals are also forms of communication. Sports communication is an aspect of communication studies which specializes in the study of communication in a sports setting (Abeza; O' Riley; \& Nadeau, 2014). It can encompass the study of inter personal and organisational communication (both verbal and nonverbal) between participants within a particular sport (e.g. players, coaches, managers, referees, trainers and physiotherapists, and governing bodies); communication between sports participants, fans, and the media, and the way that sport are represented and communicated in the media. Sports communication in something that happens at different levels ranging from preschool to college level. It is not restricted to professional, it happens constantly and works best with people that are willing to work well as a team. It is not only for positive talk, though, because negative sports communication happens all the time.

When thinking about communication in sports, the available methods can seem very specific. A quarter back used a nod of the head to indicate which direction the receiver should cut. The coaches calls a player using series of gesture known only to his or her team. Although, these forms of communication may seem particular to the game, they are analogous to non-verbal cues people use in everyday life. A nod or shelf of the head, a thumbs up, or any other motion or gesture that people use to convey something to someone else are all similar types of non-verbal communication. As far as interpersonal verbal communication goes, clear and constructive communication between players, coaches, administrators, parents and others involved with a team, parallels positive communication in any other organization-like a business.

Notwithstanding, sports communication varies vastly between individual sports and plays an important roles in the success of teams and organisations. A good example of sports communication 
and its effects on players. organisations and media was the well documented conflict involving two players for the Miami Dolphins. Inappropriate, discriminatory, and abusive interactions between Richie Incognito and Jonathan Martin led to the release of Richie from the team, organizational issues, and abundance of media coverage both negative and positive.

\subsection{Sports Administrators and Communication in Sports}

Administrators have many functions in sports organisations as they have a land in overseeing every aspect of their organisations. Alternatively, they could be responsible for communication, organizing and scheduling sports events, managing budgets or overseeing the recruitment and training of staff, coordinating and monitoring the coaching staff, interviewing prospective employees and athletes and meeting with investors, owners, or officials. Improving the communication of the staff and management of any business has been shown to maximize productivity and improve employee morale.

Sports administrators also communication in sports is an organisation's public relation with parents, media and fans. Teamy that promote positive communication and respect among players improve overall motivation. Coaches who learn to communicate effectively with their athletes, can deliver positive feedback and constructive criticism in ways that actually influence players performance.

Similarly, administrators who support open interaction in the workplace create positive working environments, which can result in more effective organisatons. Communications directly and positively with the public through every available channel (including traditional and social media) foster public support and the personal connections organisations need to build committed fan-bases.

Invariably, there are a number of issues that result in difficulty in communicating with athletes. Fitzpatrick (1988) identified some of these possible issues as;

1. The athlete's perception of something is different from the coach's perception of a situation.

2. The athlete may jump to a conclusion instead of working through the process and hearing, understanding and accepting

3. The athlete may lack the knowledge needed to understand what you are trying to communicate.

4. The athlete may lack the motivation to listen to you or to convert the information given into action

5. The coach may have difficulty in expressing what he or she wishes to say to the athlete

6. The coach may not consider the athlete's personal background or past experiences when jumping into a conclusion

7. Emotions may interfere in the communication process

8. They may be a clash of personality between the coach and the athlete

In a nutshell, researchers have shown that there are common indicators of effective communication and can apply in both sports and business.

Fitzpatrick (1988) tagged it the 6c's of communication;

- Clear - make sure your information is presented clearly

- Concise - Be short and straight to the point

- Correct - Be accurate and be careful of misleading information

- Complete - Give all the information and not just part of it

- Courteous - Be respectful of others

- Constructive - Be positive; give constructive criticism not deflating

\subsection{Empathy in Sports}

Empathy is defined as the ability to understand the thoughts, feeling or emotions of someone else. https//www.yourdirectionary.com. Examples of empathy is feeling the same amount of excitement as a team, when they say, you the leading scorer of the season. 
Empathyis understanding people feelings, entering into their world of feelings and showing them that we feel this way. I think that aiming for empathy has a significant importance, especially if we work or live in a multicultural environment or easily can find ourselves among people who are in a different situation, https://en.m. This critical skill in sports has tremendous benefits to not only athletes but also to parents and coaches. Research shows that when individuals are able to show sincere empathy to others in pain or emotional stress, it produces a powerful calming effect. This effect depends on it level of empathy that an individual can demonstrate to the distressed individual.

In sports, this can make different in a team on the verge of giving up, to push through the toughest moments of the season to finish at the top. Coaches who show empathy can inspire athletes to give more effort, increase their confidence, and even their self-worth www.gospmi.compower-empathy

Parents who are able to demonstrate high levels of empathy help their children to get toast their problems faster; therefore, refocusing on the process of getting better, instead of results.

\subsection{Tips on How to Improve Empathy Skills Among Athletes}

It is a goal of young athletes to have a career in sports world. Although, there are talented and gifted athletes willing to endure the daily rigors of their sport. But experiences has shown that very few athletes get to the top of their sport. Notwithstanding, it has become more and more evident that the attributes that separate the elite athletes from the rest are more mental than physical. And one of those overlooked attribute is the ability to show empathy towards your teammates when things don't go as planned. And, very rarely in sports do things go as planned. It is through this time that even the strongest athletes are brought to uncontrollable emotion as they come to realized their identity has just been lost. They even felt that their thousands of hours of blood, sweat, and tears have now wasted.

There is significant research that shows that sincere empathy yields positive clinical results in medicine and sports. Expressed empathy by members can produce a calming effect in athletes that creates a sense of belonging and purpose. It allows them to redirect positive energy and give them confidence needed to overcome injury by encouraging greater effort in the rehabilitation process. Teams that show empathy to their teammates create a healthy environment for everyone to work and grow. This is true whether it is the healthy superstar, the backup or role player, or the athlete who can no longer physically perform due to injury or illness. Listening, giving positive enforcement, being all-inclusive with team activities, and slowly building back self-confidence can all lead to successful return of a broken athlete.

\subsection{Statement of the Problem}

Leadership is a key process in any organization including sports perse. It has been recognized that the difference between success and failure in sports can be attributed largely to management leadership skills. The globalization of economic systems, technological advancement and increased expectations have replaced past uncertainties with new and uncertain framework. Dynamic changes of attitude of leaders in sports organization, leaders were faced with the challenges of operation in a rapidly changing world. Therefore, an effective leader should not only tray to understanding the globalization of economic societal and technological trends and how they manifest themselves today but also be involved in assessing how they are likely to impact on sports organization in future. Sports organization is very dynamic and require managers with special skills and talents in both management and leadership. Therefore, the ability to interact with others and coordinate individual and group efforts in achieving success in sports in Bayelsa East Senatorial District is the main trust of this paper.

\subsection{The Aim and Objectives of the Study}

This paper aim to assess managerial leadership skills for sports administration among sports administrators in Bayelsa East Senatorial District, Bayelsa State. Specifically, the Study seeks to

1. Determine the extent to which communication is a managerial leadership skill for effective sports administration among sports administrators in Bayelsa East Senatorial District, Bayelsa State.

2. Ascertain whether empathy is a managerial leadership skill for effective sports administration among sports administrators in Bayelsa East Senatorial District, Bayelsa State.

3. Determine the extent to which courage is used as a managerial skill among sports administrators in Bayelsa East Senatorial Distric, Bayelsa State. 
Assessment of Managerial Leadership Skills for Effective Sports Administration among Sports Administrators in Bayelsa East Senatorial District, Bayelsa State

\subsection{Research Questions}

The following research questions were formulated to guide the study

1. How does communication as managerial leadership skills relate to effective sports administration among sports administrators in Bayelsa East Senatorial District, Bayelsa State.?

2. Does empathy an effective managerial leadership skills in sports administration among sports administrators in Bayelsa East Senatorial District, Bayelsa State.

3. How does courage relate to effective managerial skills in sports administration among sports administrators in Bayelsa East Senatorial District, BayelsaState.

\subsection{Hypothesis}

The following null hypotheses were tested at an alpha of 0.05 confidence.

1. Communication will not be a significant managerial leadership skills for effective sports administration among sports administrators in Bayelsa East Senatorial District, Bayelsa State.

2. Empathy will not be a significant managerial leadership skills for effective sports administration among sports administrators in Bayelsa East Senatorial District, Bayelsa State.

3. Courage will not be a significant managerial leadership skills for effective sports administration in Bayelsa East Senatorial District, Bayelsa State.

\section{Methodology}

The descriptive survey design was used for the study. The population of 400 sports administrators comprise coaches, directors, physical educators, athletic trainers, sports secretaries, sports scientists, sports psychologists, exercise physiologists and athletes among others. The sample size of 120 sports administrators were used for the study. Multistage procedure, self-developed and validated questionnaire and three research questions guided the study. The reliability of the instrument was established through test-retest method with a reliability index of 0.65 mean scores and standard deviation were used to answer the research questions, while z-test was used to test the hypotheses at 0.05 alpha level.

\subsection{Answers to Research Questions}

\section{Research Question 1:}

How does communication as leadership traits relates to effective sports administration among sports administrators in Bayelsa East Senatorial District, Bayelsa State?

Table1. Mean scores on how communication as leadership trait relates to effective sports administration among sports administrators

\begin{tabular}{|c|c|c|c|c|c|c|c|c|}
\hline $\mathbf{S} / \mathbf{N}$ & Items & $\mathbf{S A}$ & $\mathbf{A}$ & D & SD & Mean & Rank Order & Remarks \\
\hline 1 & $\begin{array}{l}\text { Sports administrators possessed with } \\
\text { excellent written and verbal } \\
\text { communication skills among his/her team } \\
\text { members play an important role in the } \\
\text { development of sport }\end{array}$ & 66 & 76 & 46 & 12 & 2.98 & $3^{\text {rd }}$ & Agreed \\
\hline 2 & $\begin{array}{l}\text { An effective sport administrator develops } \\
\text { an effective method of keeping everyone } \\
\text { in the team abreast }\end{array}$ & 75 & 88 & 21 & 16 & 3.11 & $2^{\text {nd }}$ & Agreed \\
\hline 3 & $\begin{array}{l}\text { The failure of administrators to consult } \\
\text { other officials in the planning and } \\
\text { presenting budget proposals deteriorate } \\
\text { sport development in the district }\end{array}$ & 96 & 86 & 18 & 0 & 3.39 & $1^{\mathrm{st}}$ & Agreed \\
\hline 4 & $\begin{array}{l}\text { Every athletes have different needs and } \\
\text { perspectives, and knowing how to } \\
\text { communicate the values and expectations } \\
\text { of the program to them is a sport } \\
\text { administrators key to success }\end{array}$ & 65 & 69 & 52 & 14 & 2.93 & $4^{\text {th }}$ & Agreed \\
\hline
\end{tabular}


Assessment of Managerial Leadership Skills for Effective Sports Administration among Sports Administrators in Bayelsa East Senatorial District, Bayelsa State

Table 1 reveals that sports administrators possessed with excellent written and verbal communication skills among his/her team members play an important role in the development of sport with the mean scores 2.98. An effective sport administrator develops an effective method of keeping everyone in the team abreast with the mean score of 3.11. The failure of administrators to consult other officials in the planning and presenting budget proposals deteriorate sport development in the district with the mean score of 3.39. Every athlete have different needs and perspectives, and knowing how to communicate the values and expectations of the program to them is a sports administrators" key to success with the mean score of 2.93 respectively.

\section{Research Question 2:}

How does empathy as leadership traits relates to effective sports administration among sport administrators in Bayelsa East Senatorial Distric, Bayelsa State.?

Table2. Mean scores on how empathy as leadership traits relates to effective sport administration among sports administrators

\begin{tabular}{|c|c|c|c|c|c|c|c|c|}
\hline $\mathbf{S} / \mathbf{N}$ & Items & SA & $\mathbf{A}$ & D & SD & Mean & Rank Order & Remarks \\
\hline 5 & $\begin{array}{l}\text { Effective sports administrators are able } \\
\text { to understand the needs and perspective } \\
\text { of its athletes/team members }\end{array}$ & 65 & 77 & 50 & 8 & 3.00 & $6^{\text {th }}$ & Agreed \\
\hline 6 & $\begin{array}{l}\text { Sports administrators with empathetic } \\
\text { skills often listen attentively to what } \\
\text { their athlete/team members informed } \\
\text { them, putting their complete focus on } \\
\text { the person in front of them }\end{array}$ & 119 & 53 & 11 & 17 & 3.37 & $2^{\text {nd }}$ & Agreed \\
\hline 7 & $\begin{array}{l}\text { Ability of the sports administrators to } \\
\text { allow the club officials to offer } \\
\text { encouragement and constructive } \\
\text { criticism when team is losing } \\
\text { encourages the athletes to perform very } \\
\text { well in the next competition }\end{array}$ & 67 & 104 & 27 & 2 & 3.18 & $5^{\text {th }}$ & Agreed \\
\hline 8 & $\begin{array}{l}\text { Empathic leadership trait encourages } \\
\text { sport athletes behind poor performance } \\
\text { of his/her team }\end{array}$ & 75 & 104 & 18 & 3 & 3.26 & $3^{\text {rd }}$ & Agreed \\
\hline
\end{tabular}

Table 2 reveals that effective sports administrators are able to understand the needs and perspective of its athletes with the mean score of 3.00. Sport administrators with empathetic skills often listen attentively to what their athlete/team members informed them, putting their complete focus on the person in front of them with a mean score of 3.37. Ability of the sports administrators to allow the club officials and athletes to offer encouragement and constructive criticism when team is losing encourages the athletes to perform very well in the next competition with mean score of 3.18 . Empathic leadership trait encourages sport administrators to understand the root cause behind poor performance of his/her team with mean score of 3.26 respectively.

\section{Research Question 3:}

How does courage as leadership traits relates to effective sports administration among sports administrators in Bayelsa East Senatorial District, Bayelsa State.?

Table3. Mean scores on how courage as leadership traits relates to effective sports administration among sports administrators

\begin{tabular}{|l|l|l|l|l|l|l|l|l|}
\hline S/N & Items & SA & A & D & SD & Mean & Rank Order & Remarks \\
\hline 9 & $\begin{array}{l}\text { Effective sport administrators } \\
\text { always do what is right } \\
\text { regardless of the consequences }\end{array}$ & 75 & 88 & 21 & 16 & 3.11 & $4^{\text {th }}$ & Agreed \\
\hline 10 & $\begin{array}{l}\text { The sport administrators always } \\
\text { welcome information from club } \\
\text { officials and athletes to offer } \\
\text { encouragement and constructive } \\
\text { criticism when his team is losing } \\
\text { encourages athletes to perform }\end{array}$ & 96 & 86 & 18 & 0 & 3.39 & $1^{\text {st }}$ & Agreed \\
\hline
\end{tabular}


Assessment of Managerial Leadership Skills for Effective Sports Administration among Sports Administrators in Bayelsa East Senatorial District, Bayelsa State

\begin{tabular}{|l|l|l|l|l|l|l|l|l|}
\hline & well in the next competition & & & & & & & \\
\hline 11 & $\begin{array}{l}\text { Effective sport administrators are } \\
\text { willing to take risks in the } \\
\text { achievement of his/her goals } \\
\text { even with no assurance of } \\
\text { success }\end{array}$ & & & & & & & \\
\hline 12 & $\begin{array}{l}\text { The ability of administrator to } \\
\text { maintain good communication } \\
\text { with the press when losing } \\
\text { encourages his/her team to } \\
\text { perform well in the next } \\
\text { tournament }\end{array}$ & & 127 & 14 & 1 & 3.21 & $3^{\text {rd }}$ & Agreed \\
\hline
\end{tabular}

Table 3 reveals that effective sport administrators always do what is right regardless of the consequences with the mean score of 3.11. The sport administrators always welcome information from club officials and athletes to offer encouragement criticism when his team is losing encourages athletes to perform well in the next competition with the mean score of 3.39. Effective sport administrators are willing to take risks in the achievement of his/her goals even with no assurance of success with the mean score of 3.37. The ability of administrator to maintain good communication with the press when losing encourages his/her team to perform well in the next tournament with the mean score of 3.21 respectively.

Hypotheses 1: There is no significant difference between communication and effective sports administration among sports administrators in Bayelsa East Senatorial District in Bayelsa State

Table4. z-test Analysis of difference between Mean opinion of male and female sports administrator on Comunicating and effective sports administration among sports administrators in Bayelsa East Senatorial District in Bayelsa State

\begin{tabular}{|l|l|l|l|l|l|l|l|}
\hline Gender & $\mathbf{N}$ & $\overline{\boldsymbol{X}}$ & S.D & Df & z-cal & Critical value & Decision \\
\cline { 1 - 6 } Male & 105 & 3.9 & 1.7 & & & & Accepted \\
\cline { 1 - 5 } Female & 95 & 3.18 & 1.75 & 139 & 0.1 & 1.96 & $110_{3}$ \\
\hline
\end{tabular}

Table 4 above showed the z-test analysis of difference between the mean opinion of male and female sport administrators on Confidence and effective sport administration among sports administrators in Bayelsa East Senatorial District. The result shows that the z-calculated value of 0.1 is less than the zcritical value of 1.96 at 139 degree of freedom and 0.05 alpha significant levels. Hence, the null hypothesis was accepted. Therefore, there is no significant difference between communication and effective sport administration among sport administrators in Bayelsa East Senatorial District in Bayelsa State.

Hypotheses 2: There is no significant difference between Empathy and fective sports administration among sports administrators in Bayelsa East Senatorial District in Bayelsa State

Table5. z-test Analysis of difference between Mean opinion of male and female sports administrator on Empathy and effective sports administration among sports administrators in Bayelsa East Senatorial District in Bayelsa State

\begin{tabular}{|c|c|c|c|c|c|c|c|}
\hline Gender & $\mathbf{N}$ & $\bar{X}$ & S.D & Df & z-cal & Critical value & Decision \\
\hline Male & 120 & 2.47 & 1.57 & & & & Accepted \\
\hline Female & 80 & 2.53 & 1.59 & 200 & 1.34 & 1.96 & $110_{1}$ \\
\hline
\end{tabular}

Table 5 showed the z-test analysis of difference between the mean opionon of male and female sport administrators on Empathy and effective sports administration among sports administrators in Bayelsa East Senatorial District. The result show that the z-test calculated value of 1.34 is less than the $\mathrm{z}$ $=$ critical value of 1.96 at 200 degree of freedom and 0.05 alpha significant levels. Hence, the null hypothesis is accepted. Therefore, there is no significant difference between Empathy and effective sport administration among sport administrators in Bayelsa East Senatorial District in Bayelsa State.

Hypotheses 3: There is no significant difference between courage and effective sports administration among sports administrators in Bayelsa East Senatorial District in Bayelsa State 
Assessment of Managerial Leadership Skills for Effective Sports Administration among Sports Administrators in Bayelsa East Senatorial District, Bayelsa State

Table5. z-test Analysis of difference between Mean opinion of male and female sports administrator on Courage and effective sports administration among sports administrators in Bayelsa East Senatorial District in Bayelsa State

\begin{tabular}{|l|l|l|l|l|l|l|l|}
\hline Gender & $\mathbf{N}$ & $\overline{\boldsymbol{X}}$ & S.D & Df & z-cal & Critical value & Decision \\
\hline Male & 115 & 2.9 & 1.7 & & & & $\begin{array}{l}\text { Accepted } \\
\text { Female }\end{array} 85$ \\
\hline
\end{tabular}

Table 5 showed that z-test anlaysis of difference between the mean opinion of male and female sport administrators on courage and effective sport administration among sport administrators in Bayelsa East Senatorial District. The result shows that the z-calculated value of 0.27 is less than the z-critical value of 1.96 at 200 degree of freedom and 0.05 alpha significant levels. Hence, the null hypothesis is accepted. Therefore, there is no significant difference between Courage and effective sport administration among sport administrators in Bayelsa East Senatorial District in Bayelsa State.

\section{DISCUSSION OF FINDINGS}

\subsection{Courage and Effective Sports Administration}

The study revealed that effective sports administrators always do what is right regardless of the consequences. The sport administrators always welcome information from school officials and athletes to offer encouragement, criticism when his team is losing encourages athletes to perform well in the next competition. Effective sport administrators are willing to take risks in the achievement of his/her goals even with no assurance of success. The ability of administrator to maintain good communication with the press when team is losing encourages his/her team to perform well in the next tournament.

This is in line with Bill (2010) on 10 laws of leadership. He said that is the inner strength, presence of mind against odds, determination to hang in there, to venture, persevere, and withstand hardship or circumstances even in the face of failure. He also said that leadership is often a battle, and the fight requires courage. Have courage doesn't mean you'll have no inner turmoil. Having courage means that you will do what is right, regardless of the consequences. He added that courage is resistance to fear, mastery of fear, not absence of fear. Effective sport administrator stands and executes his/her jobs even in the face of crises.

\subsection{Communication and Effective Sports Administration}

The study reveals that sport administrators possessed with excellent written and verbal communication skills among his/her team members play an important role in the development of sport. An effective sport administrator develops an effective method of keeping everyone in the team abreast. The failure of administrators to consult other officials in the planning and presenting budget proposals deteriorate sport development in the district. Every athlete have different needs and perspectives, and knowing how to communicate the values and expectations of the program to them is a sport administrators key to success.

This is in line with Barrett (2006) who noted that smart communication skills facilitate to develop higher understanding and beliefs among people inspire them to follow the principle associate degreed values that their leaders needs to infuse in them. Effective and correct communication acts as an important issue to grow as an efficient and convincing communicators. This is also in line with the work of (Weston, 2015) who said that the last and most important piece of advice for dealing and adapting to change is communication. Clear and concise communication between leaders and followers helps all involved and adjust to change more efficiently.

\subsection{Empathy and Effective Sports Administration}

The study reveals that effective sport administrators are able to understand the needs and perspective of its athletes. Sports administrators with empathetic skills often listen attentively to what their athlete/team members informed them, putting their complete focus on the person in front of them. Ability of the sports administrators to allow the school officials and students to offer encouragement and constructive criticism when team is losing encourages the athletes to perform very well in the next competition. Empathic leadership trait encourages sports administrators to understand the root cause behind poor performance of his/her team. 


\section{CONCLUSION}

Based on the findings of the study, it was concluded that managerial skills are essential to professional practice in sports organization. And by the virtue of the formal roles of sports administrators, they are responsible for empowering subordinates to establish and achieve goals through effective communication, empathy and courage. The extent of their leadership skills will largely dictate the outcome of the actions of their athletes

\section{RECOMMENDATIONS}

1. Sports administrators should use their managerial skills to motivate, train and direct sub-ordinates energies and efforts towards accomplishing, organizational goals.

2. Participation in sport should be based upon the concepts of fairness, sportsmanship, respect, responsibility and safety.

3. The medium of communication between the players, spectators, coaches, managers and sports organization involved in the organization and management of sports competitions should be properly harnessed to reinforce performance excellence.

\section{REFERENCES}

[1] Griffin, R.W. (1999). Management $6^{\text {th }}$ edition. New York: Houghton Miffin Company

[2] Weston, B. (2015, February 23). 10 tips dealing with change positively in your workplace. Retrieved from https://www.linein.com/pulse/10-tips-dealing-change-positively-yourworkplace-ban-weston/

[3] Singh, A.S.; 11, J.S.; Bains J. \&Brar, R.S. (2014).Essential of physical education, Indian; Kai Yani Publishers.

[4] Here P. \& Blanchard, K.H. 1988). Management of organizational behaviour; utilizing human resources ( $7^{\text {thed}}$ ). Upper Sadle River, NJ; Prentice Hall.

[5] Mull, F.; Bayless, K.G. \& Jamieson, L.M. (2003).Recreational sport management: $4^{\text {th }}$ edition, Human Kinetics, USA.

[6] Ibrahim, L.V. (2016). Effective managerial leadership and challenges in sports organization. Journal of Sports and Physical Education (10SR-JSPE), 3(50 73-80

[7] Fitzpatrick, A.M. (1988). The six C's of effective communication, Health progress, March: 96-101

Citation: Dr. Deemua G.A. "Assessment of Managerial Leadership Skills for Effective Sports Administration among Sports Administrators in Bayelsa East Senatorial District, Bayelsa State" International Journal of Humanities Social Sciences and Education (IJHSSE), vol 7, no. 11, 2020, pp. 45-53. doi: https://doi.org/10.20431/2349-0381.0711006.

Copyright: (c) 2020 Authors. This is an open-access article distributed under the terms of the Creative Commons Attribution License, which permits unrestricted use, distribution, and reproduction in any medium, provided the original author and source are credited. 